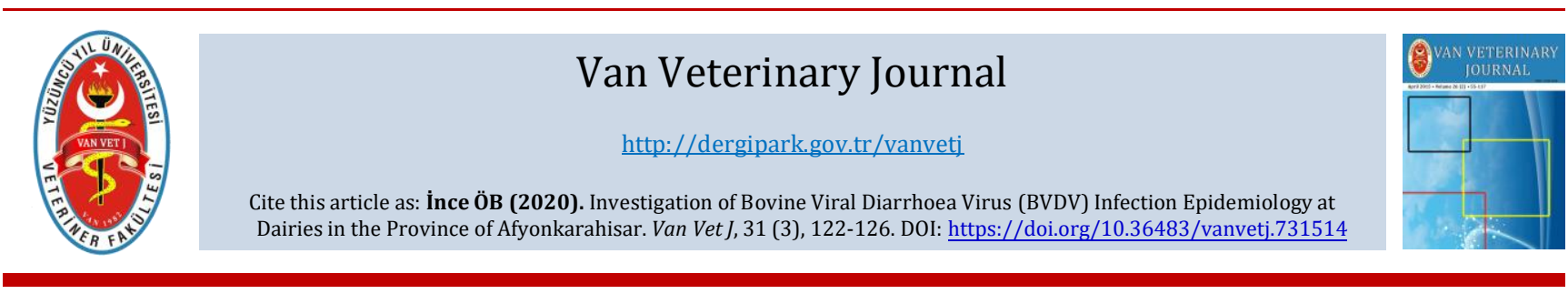

\title{
Investigation of Bovine Viral Diarrhoea Virus (BVDV) Infection Epidemiology at Dairies in the Province of Afyonkarahisar
}

\author{
Ömer Barıș İNCE® \\ Pamukkale University, Animal Breeding and Genetic Research and Implementation Center, Denizli, Turkey
}

Received: 03.05.2020

Accepted: 21.07.2020

\begin{abstract}
Bovine Viral Diarrhoea Virus (BVDV) is a cause of viral diseases in cattle, which are commonly seen around the world and cause considerable reproductive problems and economic loss. This study was conducted to investigate the epidemiology of BVDV infection in in dairy cattle herds in the Afyonkarahisar Province. In this study, blood samples were taken from a total of 240 cows from dairy herds $(n=10)$ between 2017 and 2019. Serum samples were examined by using commercial ELISA test kits in order to determine the presence of antibody (Ab) and antigen (Ag) against BVDV. According to the test results, 98 (40.83\%) of the serum samples were found to be positive while $4(1.67 \%)$ of them had persistent infection. In addition, samples were found to be seropositive at the rate of $18.06 \%, 44.80 \%$ and $67.44 \%$ for the age groups of $6-24$ months, $24-48$ months and over 48 months, respectively. It was determined that the seropositivity among age groups were statistically significant $(\mathrm{P}<0.05)$. It was observed that the age-related seropositivity of animals increased in direct proportion. The data obtained from the results of this study show the presence of BVDV infection at the dairy cattle herds in Afyonkarahisar and nearby provinces. For this reason, implementation of the voluntary or obligatory eradication programs to prevent for prevention of further spread of this virus, are of importance for regional and national economy.
\end{abstract}

Keywords: Cattle, BVDV, Epidemiology, ELISA

öz

\section{Afyonkarahisar İli Süt Sığırı İşletmelerinde Bovine Viral Diyare Virus (BVDV) Enfeksiyonunun Epidemiyolojik Araştırılması}

Bovine Viral Diarrhoea Virus (BVDV) dünya genelinde yaygın olarak gözlemlenen ve önemli üreme problemlerine ve ekonomik kayıplara neden olan sı̆̆ırların viral hastalık etkenidir. Bu çalışma Afyonkarahisar İli süt sığırı işletmelerinde BVDV enfeksiyonu epidemiyolojisinin araştırılması amacıyla yapıldı. Çalıșma kapsamında 2017-2019 yılları arasında süt sığırı işletmelerinden $(n=10)$ toplamda 240 adet dişi sığır kan örnekleri toplandı. Serum örnekleri BVDV'ye karşı antikor (Ab) ve antijen (Ag) varlığını belirlemek için ticari ELISA test kitleri kullanılarak incelendi. Test sonuçlarına göre serum örneklerinin 98'i (\%40.83) pozitif ve 4 tanesi (\%1.67) persiste enfekte bulundu. Ayrıca örnekler, 6- 24 ay, 24-48 ay ve 48 ay üstü yaş aralığında sırasıyla \%18.06, \%44.80 ve \%67.44 seropozitif bulundu. Yaş grupları arasındaki seropozitifliğin istatistiksel açıdan anlamlı olduğu belirlendi $(\mathrm{P}<0.05)$. Hayvanların yaşa ilişkin olarak seropozitifliğin doğru orantılı arttığı gözlemlendi. Mevcut çalışmanın sonuçlarından elde edilen veriler, Afyonkarahisar İli ve çevresinde bulunan süt sığırcılığı işletmelerinde BVDV enfeksiyonunun varlığını göstermektedir. $\mathrm{Bu}$ nedenle söz konusu viral etkenin daha fazla yayılmasını önlemek için gönüllü veya zorunlu eradikasyon program uygulamalarının bölge ve ülke ekonomisi için önem arz etmektedir.

Anahtar Kelimeler: Siğır, BVDV, Epidemiyoloji, ELISA

\section{INTRODUCTION}

BVD is a worldwide cattle disease included in the OIE list which is known for its important effect on animal health, welfare and production (OIE 2017). BVDV belongs to the Pestivirus genus in the family Flaviviridae, It has a single strand stranded of positive-sense RNA. BVDV is globally found in domestic and wild ruminants, and its symptoms are fever, gastrointestinal lesions, diarrhea, abortion in pregnant cattle, congenital defects, malformations and mortality in new born calves (Lanyon et al. 2014; Şevik 2018; Mirosław and Polak 2019). Vertical infection in early pregnancy period may result in the birth of persistently infected calves, which is highly important in epidemiology 
of BVDV persistent infection (Nikbakht et al. 2015). After infection is identified in a herd, it progresses in two forms as persistent infection and transient infection. Persistent infections are the main epidemiological agents causing spread and persistency of a disease in a cattle herd (Ezannoet al. 2007). Persistently infected animals are of greater importance compared to transiently infected cattles, since they carry BVDV throughout their life and are the main source for transmission of the virus (Brownlie et al. 1987; Scharnböck et al. 2018; Olum et al. 2020). BVDV infected cattle may be seronegative during the first 40-120 days of gestation however; infection may lead to the birth of persistently infected calves. If the persistently infected animals shed virus in high titres and they are not taken away from the herd after being identified, they cause BVDV to remain within the herd (Lindberg and Houe 2005; Mirosław and Polak 2019).

Although BVDV infection is detected in persistently infected animals at the rate of $1-2 \%$ across the world, a prevalence varying between $40-90 \%$ has been reported (Houe 1995; Duong et al. 2008; Zemke et al. 2010). In Turkey, the prevalence of BVDV infection varies between the rates of $40-92 \%$ while persistently infected animal presence changes between 0.01-4.9\% (Alkanet al. 2001; Burgu et al. 2003; Avcl and Yavru 2013; Bilgili and Mamak 2019). Seroprevalence of the BVDV infection and the role of BVDV in clinical pictures of the disease have been identified in the studies conducted in Turkey (Bilgili and Mamak 2019).

ELISA kits are preferred in studies on BVDV infection since they provide fast screening of many samples, and they are sensitive and economic (Alvarez et al. 2012; Tavella et al. 2012; Lanyon et al. 2013; Gonzalez et al. 2014; Hanon et al. 2018). In this study, epidemiology of BVDV infection was investigated by using ELISA method in dairy cattle herds in the Afyonkarahisar Province.

\section{MATERIALS and METHODS}

\section{Collecting, processing and preserving samples}

In this study, 240 Holstein dairy cows, aged between 6-60 months, were sampled from dairy cattle herds $(n=10)$ by random sampling. All sampled cattle were clinically healthy and were not vaccinated against BVDV. Blood samples $(10 \mathrm{ml})$ were taken from vena jugularis of animals in compliance with animal welfare. Then, blood samples were centrifuged at $3000 \mathrm{rpm}$ for 10 minutes in order to obtain serum. Blood samples were kept at $-20^{\circ} \mathrm{C}$ until analysis after having been subjected to inactivation by being kept at $56^{\circ} \mathrm{C}$ for 30 minutes.

\section{ELISA Test and Statistical analysis}

This study was conducted by using BVDV (Ab)-ELISA (IDEXX BVDV-Total Ab, Switzerland) and BVDV (Ag)-ELISA (IDEXX BVDV Ag test, Switzerland) commercial kits. Collected serum samples were examined by indirect ELISA (BVDV-(Ab) ELISA) regarding the presence of antibody developing against BVDV. The optical density (OD) values of test results were read in an ELISA reader at $450 \mathrm{~nm}$ wavelength. Antibody inhibition percentages of serum samples were calculated in line with the following formula.

$$
\% \text { İnhibition }=\frac{O D \text { values of samples }}{\text { Negative OD value }} \times 100
$$

The samples with values of 0.30 and below were evaluated as negative, those between 0.20 and 0.30 were assessed suspect, and those above 0.30 were accepted positive.
The test, based on the principle of identifying viral antigens in study samples for detection of BVDV antigen presence, was conducted in accordance with the procedures of producing company. Data processing was performed in R program (R Core Team 2018). Chi-square tests were utilized in order to investigate whether there were any relationships between age groups. $\mathrm{P}<0.05$ value was accepted statistically significant.

\section{RESULTS}

According to indirect ELISA test results in terms of antibody, out of 240 cattle, 98 were found positive $(40.83 \%)$ and 142 were found negative $(59.17 \%)$. The cattle were categorized into 6-24 months, 24-48 months and above 48 months distribution according to age groups. Thirteen $(18.06 \%)$ of 72 animals in the $6-24$ months age group, $56(44.80 \%)$ of 125 animals in the $24-48$ months age group and $29(67.44 \%)$ of 43 animals in above 48 months age group were found to be positive, respectively (Table 1 and 2).

A total of 4 animals were found to be positive in 1 herd in terms of antigen according to indirect ELISA test results. Taking the state of persistently infected animals into account, blood samples were received from the animals with positive results for the second time after 45 days to look for antigen. As the test results of these 4 animals were found to be positive for the second time, they were considered persistently infected y animals (Table 1).

\section{DISCUSSION}

It is known that persistently infected animals in herds are the main causes of prevalence and spread of BVDV infection in cattle herds and that many virus particles are transmitted through these animals. It is urged that the cause spreading to persistently infected young cows depends on the increase in prevalence of disease (Schweizer and Peterhans 2014; Ran et al. 2019). It is also argued that it is necessary to apply intervention methods, including sorting strategy and animal vaccination, in order to reduce BVDV prevalence in herds, including the herds with persistently infected animals (Newcomer et al. 2017). The calves born with persistent BVDV infection, and infertility and, calve with congenital anomalies show the significance of the disease in economical respect. For this reason, in this study, the samples were investigated in terms of antigen and antibody presence in order to assess BVDV infection in epidemiological respects. The investigation concluded that while $98(40.83 \%)$ animals were found to be positive for antibody, $4(1.67 \%)$ animals were found to be positive in terms of antigen. It was reported in interviews made with the herd owners that abortion cases were previously seen in some herds. In this regard, it is argued that BVDV antibody positive rate of $40.83 \%$ may be related to the sampling of the animals, which were infected and then recovered.

In our country, the studies on prevalence of BVDV in epidemiological respects have been carried out from time to time. The seropositivity rates found in some studies conducted in Turkey are as follows: $86 \%$ in the study carried out by Tan et al. (2006) in the province of Aydın and its surrounding, $20.19 \%$ in the study conducted by Yazicl et al. (2007) in the province of Sivas and its surrounding, $75-82 \%$ in the study conducted by Kale (2007), Öztürk et al. (2012) in the province of Burdur and its surrounding, $49.9 \%$ in the study performed by Şişman 
(2008) in the province of Muğla and its surrounding, $75.22 \%$ in the study by Bilgili and Mamak (2019) in the province of Isparta and its surrounding. In addition, the following seropositivity rates were found in the studies carried out in Konya and its surrounding: $79.5 \%$ in the study by Şimșek and Öztürk (1997), 44.09\% in the study by Yavru et al. (2005), 46.22\% in the study by Avcl and Yavru (2013). In this study, BVDV infectionrevalence was found to be $40.83 \%$. This rate is similar to the rates found by Yavru et al. (2005), Avcl and Yavru (2013) in the studies carried out in Konya and its surrounding and by Şișman (2008) in the study conducted in the province of Muğla and its surrounding. This rate is lower than the ones identified in the studies administrated in the provinces of Aydın, Burdur and Isparta. It is considered that this may be associated with the sample number used in the study, care and feeding conditions of animals.

In some cases, the BVDV prevalence may have relationship with age range, herd size and type or raising method (Fulton et al. 2009; Ma et al. 2016; Selim et al. 2018). It was determined in the distribution of age groups in this study that as the age increased, the positivity increased according to the correlation test between positivity and seronegativity. The relationship among age groups was found to be statistically significant $(\mathrm{P}<0.05)$. This result is in parallel with the ones found by other researchers (Mockeliuniene et al. 2004). Epidemiological studies on the positivity rate of persistently infected animals have been carried out in the world and Turkey. While the prevalence of persistently infected animals in a herd varies between $1-2 \%$ across the world, it is argued that the high positivity rate is an indicator of presence of persistently infected animal presence in a herd (Houe and Meyling 1991; Houe 1999; Wittum et al. 2001; Hashemi et al. 2010).

The persistent infection rate in the studies conducted in different regions of our country have been reported as follows: $0.7 \%$ by Şimşek and Öztürk (1997), 3.07\% by Ak et al. (2002), $0.61-0.83 \%$ by Burgu et al. (2003), $0.1 \%$ by Bulut et al. (2006), 4.9\% by Tan et al. (2006). In this study, 4 of 240 animals $(1.67 \%)$ were determined to be persistently infected. The persistent infection rate found in this study is in compliance with the rate found by other researchers (Şimșek and Öztürk 1997; Burgu et al. 2003; Houe and Meyling, 1991; Houe 1999; Wittumet al. 2001; Bulut et al. 2006; Hashemi et al. 2010). While percentage differences in the study may originate from the fact that persistently infected animals were removed from the herd in previous studies (Şimșek and Öztürk 1997; Bulut et al. 2006) conducted in related study fields, no persistently infected animals could be identified or existed in related areas; high persistent infection rate may arise from the lack of awareness of taking protection and control measures against BVDV infection. When the seropositivity and persistent infection rate of BVDV infection are evaluated together, it may be noted that removing persistently infected animals from herds, taking and applying bio safety measures, ensuring protection and control of the disease are importance for livestock sector

Table 1. Results of the BVDV-Ab and BVDV-Ag Analyses

\begin{tabular}{|c|c|c|c|c|c|c|c|c|c|}
\hline \multirow[b]{2}{*}{$\begin{array}{l}\text { Number } \\
\text { Herds }\end{array}$} & & \multirow[b]{2}{*}{$\begin{array}{l}\text { Number } \\
\text { Samples }\end{array}$} & \multirow[b]{2}{*}{ of } & \multicolumn{3}{|c|}{ BVDV (Ab)-ELISA } & \multicolumn{3}{|c|}{ BVDV (Ag)-ELISA } \\
\hline & & & & Positive & Negative & Percentage & Positive & Negative & Percentage \\
\hline 1 & & 28 & & 8 & 20 & $28.57 \%$ & 0 & 28 & $0.00 \%$ \\
\hline 2 & & 30 & & 19 & 11 & $63.33 \%$ & 4 & 29 & $13.33 \%$ \\
\hline 3 & & 27 & & 13 & 14 & $48.15 \%$ & 0 & 27 & $0.00 \%$ \\
\hline 4 & & 24 & & 9 & 15 & $37.50 \%$ & 0 & 23 & $0.00 \%$ \\
\hline 5 & & 18 & & 8 & 10 & $44.44 \%$ & 0 & 18 & $0.00 \%$ \\
\hline 6 & & 20 & & 13 & 7 & $65.00 \%$ & 0 & 20 & $0,00 \%$ \\
\hline 7 & & 15 & & 5 & 10 & $33.33 \%$ & 0 & 15 & $0.00 \%$ \\
\hline 8 & & 27 & & 6 & 21 & $22.22 \%$ & 0 & 25 & $0.00 \%$ \\
\hline 9 & & 26 & & 8 & 18 & $30.77 \%$ & 0 & 26 & $0.00 \%$ \\
\hline 10 & & 25 & & 9 & 16 & $36.00 \%$ & 0 & 25 & $0.00 \%$ \\
\hline Total & & 240 & & 98 & 142 & $40.83 \%$ & 4 & 236 & $1.67 \%$ \\
\hline
\end{tabular}

Table 2. Percentage of animals between age groups.

\begin{tabular}{lllll}
\hline Age & Number of samples & Positive & Negative & Percentage* $^{*}$ \\
\hline 06-24 months & 72 & 13 & 59 & $18.06 \%$ \\
24-48 months & 125 & 56 & 69 & $44.80 \%$ \\
48 months $<$ & 43 & 29 & 14 & $67.44 \%$ \\
Total & 240 & 98 & 142 & $40.83 \%$ \\
\hline
\end{tabular}

$* \mathrm{P}<0.05$ 


\section{CONCLUSION}

BVDV infection is considered as a problem in the dairy cattle herds. In Turkey, any voluntary or obligatory control and eradication programs have not been introduced against the BVD disease yet. The herds are trying to establish control with inactive BVDV vaccines. It has been concluded that more comprehensive research should be carried out in planning and implementation of a wide range of voluntary or obligatory eradication programs on a regional and national basis in order to reduce the incidence of diseases related to BVDV infection.

\section{CONFLICT of INTEREST}

The author declares that she has no conflict of interest.

\section{ACKNOWLEDGMENTS}

In this study, no human-related data were collected and all data were obtained on the basis of routine veterinary medicine and owners of animals allowed the blood sampling. Animal welfare and ethical rules were considered in taking blood samples. This study does not involve any animal experiment or human subject. The author thanks to his colleagues and technicians at the Ministry of Agriculture and Forestry, provincial organization due to their support in this study.

\section{REFERENCES}

Alkan F, Yeşilbağ K, Burgu İ (2001). Persiste Enfekte Sı̆̆ırlarda BVDV 'nin Organ Dağılımı. Ankara Üniv Vet Fak Derg, 48, 111-115.

Ak S, Firat İ, Bozkurt HH et al. (2002). The Prevalence of Bovine Viral Diarrhoea Virus (BVDV) Infections in Cattle and Existence of Persistently Infected Cattle in the Trakya Region. Turk J Vet Anim Sci, $26,245-248$.

Alvarez M, Donate J, Makoschey B (2012). Antibody Responses against Non-Structural Protein 3 of Bovine Viral Diarrhoea Virus in Milk and Serum Samples from Animals Immunised with an Inactivated Vaccine. Vet J, 191, 371-376.

Avcı 0, Yavru S (2013). Investigation of Bovine Herpesvirus-1, Bovine Viral Diarrhea Virus and Bovine Herpesvirus-4 in a Dairy Herd with Naturally Infected in Konya. Eurasian J Vet Sci, 29, 82-86.

Brownlie J, Clarke MC, Howard CJ et al. (1987). Pathogenesis and Epidemiology of Bovine Virus Diarrhoea Virus Infection of Cattle. Annal Vet Res, 18(2), 157-166.

Bilgili İ, Mamak N (2019). Isparta İli ve Çevresinde Sığırcılık İsletmelerinde Bovine Viral Diyare Virus (BVDV) Enfeksiyonunun Serolojik Olarak Araştırılması. MAKU J Health Sci Inst, 7(2), 105-113.

Bulut O, Yavru S, Yapkıç O (2006). Sütçü Sığırların Bovine Herpesvirus 1 (BHV-1) ve Bovine Viral Diarrhoea Virus (BVDV) Enfeksiyonları Yönünden Elısa ile Araştırılması. Hay AraşDerg, 16(2), 18-24.

Burgu İ, Alkan F, Özkul A et al. (2003). Türkiye'de Süt Sığırcılığ İșletmelerinde Bovine Viral Diarrhea (BVDV) Enfeksiyonunun Epidemiyolojisi ve Kontrolü. Ankara Üniv Vet Fak Derg, 50, 127-133.

Duong MC, Alenius S, Huong LTT et al. (2008). Prevalence of Neospora Caninum and Bovine Viral Diarrhoea Virus in Dairy Cows in Southern Vietnam. Vet J, 175(3), 390-394.

Ezanno P, Fourichon C, Viet AF et al. (2007). Sensitivity Analysis to Identify Key-Parameters in Modelling the Spread of Bovine Viral Diarrhoea Virus in A Dairy Herd. Prev Vet Med, 80, 49-64.

Fulton RW, Whitley EM, Johnson BJ et al. (2009). Prevalence of Bovine Viral Diarrhea Virus (BVDV) in Persistently Infected Cattle and Bvdv Subtypes in Affected Cattle in Beef Herds in South Central United States Can J Vet Res, 73, 283-291.

Gonzalez AM, Arnaiz I, Yus E, et al. (2014). Evaluation of Long-Term Antibody Responses to Two Inactivated Bovine Viral Diarrhoea Virus (BVDV) Vaccines. Vet J, 199, 424-428.

Hanon JP, Baere MD, Ferté C, et al. (2018). Serological Monitoring on Milk and Serum Samples in a BVD Eradication Program: A Field Study in Belgium Showing Antibody ELISA Performances and Epidemiological Aspects. Prev Vet Med, 160, 136-144.
Hashemi GR, Haghparast A, Naseri, Z (2010). Prevalence of Bovine Viral Diarrhea Virus Antibodies and Antigen among the Aborted Dairy Cows in Industrial Dairy Cattle Herds in Mashhad Area-Iran. World Applied Sciences J, 8(5), 635-640.

Houe H (1995). Epidemiology of Bovine Viral Diarrhoea Virus Veterinary Clinics of North America. Food Animal Practice, 11, 521-547.

Houe $\mathbf{H}$ (1999). Epidemiological Features and Economical Importance of Bovine Virus Diarrhoea Virus (BVDV) Infections. Vet Microbiol, 64(2-3), 89-107.

Houe H, Meyling A (1991). Prevalence of Bovine Virus Diarrhoea (BVD) in 19 Danish Dairy Herds and Estimation of Incidence of Infection in Early Pregnancy. Prev Vet Med, 11, 9-16.

Kale M (2007). Sığırlarda Bovine Viral Diarrhea Virus (BVDV) EnfeksiyonununFertiliteileIllișkisininAraștırılması. TÜBITAK Projesi. Proje No: 1060366 Burdur. s. 1-116.

Lanyon SR, Anderson M, Bergman E et al. (2013). Validation and Evaluation of a Commercially Available Elısa for the Detection of Antibodies Specific to Bovine Viral Diarrhoea Virus (Bovine Pestivirus). Aust Vet J, 91, 52-56.

Lanyon SR, Hill FI, Reichel MP et al. (2014). Bovine Viral Diarrhoea: Pathogenesis and Diagnosis. Vet J, 199, 201-209.

Lindberg A, Houe H (2005). Characteristics in the Epidemiology of Bovine Viral Diarrhea Virus (BVDV) of Relevance to Control. Prev Vet Med, 72, 55-73.

Ma JG, Cong W, Zhang FH, et al. (2016). Seroprevalence and Risk Factors of Bovine Viral Diarrhoea Virus (BVDV) Infection in Yaks. (Bos grunniens) in Northwest China. Trop Anim Health Prod, 48, 1747-1750.

Mockeliuniene V, Salomskas A, Mockeliunas R, et al. (2004). Prevalence and Epidemiological Features of Bovine Viral Diarrhoea Virus Infection in Lithuania. Vet Microbiol, 99, 51-57.

Mirosław P, Polak M (2019). Increased genetic variation of bovine viral diarrhea virus in dairy cattle in Poland. BMC Vet Res. 15(1), 278. doi: 10.1186/s12917-019-2029-z. Avaible from: https://bmcvetres.biomedcentral.com/articles/10.1186/s12917-0192029-z Access date:12.09.2019

Newcomer BW, Chamorro MF, Walz PH (2017). Vaccination of Cattle against Bovine Viral Diarrhea Virus Vet Microbiol, 206, 78-83.

Nikbakht G, Tabatabaei S, Lotfollahzadeh $S$ et al. (2015). Seroprevalence of Bovine Viral Diarrhoea Virus, Bovine Herpesvirus 1 and Bovine Leukaemia Virus in Iranian Cattle and Associations among Studied Agents. J App Ani Res, 43(1), 22- 25.

OIE. (2017). Listed Diseases, Infections and Infestation in Force in 2017 World Organisation for Animal Health. Avaible from: https://www.oie.int/en/animal-health-in-the-world/oie-listeddiseases-2017/ Access date: 02.08.2019

Olum MO, Mungube EO, Njanja J et al. (2020). Seroprevalence of Canine Neosporosis and Bovine Viral Diarrhoea in Dairy Cattle in Selected Regions of Kenya. TransboundEmerg Dis,doi: 10.1111/tbed.13429 Avaible from: Avaible
https://onlinelibrary.wiley.com/doi/abs/10.1111/tbed.13429 Access date:10.04.2020.

Öztürk D, Kale M, Pehlivanoğlu F et al. (2012). Evaluation for Some Bacterial and Viral Abortions of Dairy Cattle Farms in Burdur District of Turkey. KafkasÜniv Vet FakDerg, 18(2), 255-258.

R Core Team 2018. R: A Language and Environment for Statistical Computing. R Foundation for Statistical Computing, Vienna, Austria. Available online: http://www.R-project.org. Access date; 01.06.2018.

Ran X, Chen X, Ma L, et al. (2019). A Systematic Review and Meta-Analysis of the Epidemiology of Bovine Viral Diarrhea Virus (BVDV) Infection in Dairy Cattle in China. Acta Tropica, 190(2), 296-303.

Scharnböck B, Roch FF, Richter V et al. (2018). A Meta-Analysis of Bovine Viral Diarrhoea Virus (BVDV) Prevalences in the Global Cattle Population. Scientific Reports, 8(1), 14420.

Schweizer M, Peterhans E (2014). Pestiviruses. Annu Rev AnimBiosci, 2, 141-163.

Selim AM, Elhaig MM, Moawed SA et al. (2018). Modeling the Potential Risk Factors of Bovine Viral Diarrhea Prevalence in Egypt Using Univariable And Multivariable Logistic Regression Analyses. Vet World, 11, 259-267.

Şevik M (2018). The Role of Pestiviruses (BDV and BVDV) in Ruminant Abortion Cases in the Afyonkarahisar Province. Kocatepe Vet J, 11(3), 238-244.

Şimşek A, Öztürk F (1997). Klinik Olarak Sağlıklı Sığır SürülerindePersiste Bovine Viral Diarrhea Virus Enfeksiyonlarının Araştırılması ve Epizootiyolojik Önemi. Vet Bil Derg, 13(2), 113-119.

Şişman E (2011). Muğla İli veçevresindesığırcılıkişletmelerinde Bovine Viral Diyare (BVDV) enfeksiyonunun serolojik olarakar aștırılması. Yüksek Lisans Tezi. Yüzüncü Yıl Sağlık Bilimleri Enstitüsü, Van. 
Tan MT, Karaoğlu T, Erol N et al. (2006). Serological and Virological Investigations of Bovine Viral Diarrhoea Virus (BVDV) Infection in Dairy Cattle Herds in Aydın province. TurkJ Vet Anim Sci, 30, 299-304.

Tavella A, Zambotto $\mathbf{P}$, Stifter $\mathbf{E}$ et al. (2012). Investigation to the Specificity of Positive BVDV Results in Ear Notch Samples: Review on The Five-Year-Old Experience in the Autonomous Province of Bolzano (Italy). Berl Munch Tierarztl Wochenschr. 125, 326-331.

Wittum TE, Grotelueschen DM, Brock, K.V et al. (2001). Persistent Bovine Viral Diarrhoea Virus İnfection in US Beef Herds. Prev Vet Med $49,83-94$.
Yavru S, Şimşek A, Yapkıç O et al. (2005). Serological Evaluation of Viral Infections in Bovine Respiratoy Tract. Acta Vet Beograd, 55, 219-226.

Yazıcı Z, Okur GS, Albayrak H (2007). Serological Profile of some Viral Infections in Unvaccinated Cattle in Turkey. MedycynaWeterinaryjna. 63(2), 187-189.

Zemke J, Konig P, Mischkale K, Reimann I, Beer M (2010). Novel BVDV2 Mutants as New Candidates for Modified-Live Vaccines. Vet Microbiol, 142(1-2), 69-80. 